\title{
IBTIDA
}

Jurnal Kajian Pendidikan Dasar

Vol. 1 No 1, Tahun 2021

\section{PENGARUH KEPEMIMPINAN TRANSFORMASIONAL KEPALA SEKOLAH, BUDAYA SEKOLAH, DAN LINGKUNGAN SEKOLAH TERHADAP KINERJA GURU DI MI ISLAMIYAH WARENG, BUTUH, PURWOREJO, JAWA TENGAH}

\author{
Icha Nurfasicha \\ (SMK N 2 Purworejo)
}

\author{
Muarif Mahmud Suhada \\ (MTs N 8 Kebumen) \\ muarifsuhada@yahoo.co.id
}

Faizin

(Disdikbud Purbalingga)

faizinfaiz689@gmail.com

\begin{abstract}
ABSTRAK
Penelitian ini didasari oleh permasalahan kinerja guru yang belum memuaskan. Sehubungan dengan hal tersebut, penelitian ini bertujuan untuk mengetahui pengaruh kepemimpinan transformasional kepala sekolah, budaya sekolah, dan lingkungan sekolah terhadap kinerja guru di mi islamiyah wareng, butuh, purworejo, jawa tengah. Penelitian ini merupakan penelitian kuantitatif korelasional. Populasi dan sampel dalam penelitian ini adalah seluruh guru-guru MI Islamiyah Wareng Butuh Purworejo Jawa Tengah, yang berjumlah 12 orang. Pengumpulan data menggunakan angket, dan analisis data menggunakan teknik analisis regresi sederhana dan regresi ganda. Penelitian ini menghasilkan kesimpulan sebagai berikut. (1) Kepemimpinan Transformasional Kepala Sekolah memiliki pengaruh yang tidak signifikan terhadap Kinerja Guru MI Islamiyah Wareng Butuh Purworejo Jawa Tengah, terbukti dari nilai Sig $=0,866>\alpha=0,05$. Adapun nilai koefisien korelasi $\left(\mathrm{r}^{2}\right)=$ 0,003 atau hanya berkontribusi sebesar 0,3\%. (2) Budaya Sekolah memiliki pengaruh yang signifikan terhadap Kinerja Guru MI Islamiyah Wareng Butuh Purworejo Jawa Tengah, terbukti dari nilai Sig $=0,01<\alpha=0,05$. Adapun nilai koefisien korelasi $\left(\mathrm{r}^{2}\right)=0,503$ atau berkontribusi sebesar 50,3\%. (3) Lingkungan Sekolah memiliki pengaruh yang tidak signifikan terhadap Kinerja Guru MI Islamiyah Wareng Butuh Purworejo Jawa Tengah, terbukti dari nilai Sig $=0,169>\alpha=0,05$. Adapun nilai koefisien korelasi $\left(\mathrm{r}^{2}\right)=0,180$ atau hanya berkontribusi sebesar 18,0\%. (4) Kepemimpinan Transformasional Kepala Sekolah, Budaya Sekolah, dan Lingkungan Sekolah secara bersama-sama memiliki pengaruh yang tidak signifikan terhadap Kinerja Guru MI Islamiyah Wareng Butuh Purworejo Jawa Tengah, terbukti dari nilai $\mathrm{Sig}=0,103>\alpha=0,05$. Adapun nilai koefisien korelasi $\left(\mathrm{R}^{2}\right)=0,519$ atau berkontribusi sebesar 51,9\%.
\end{abstract}

Kata kunci: kepemimpinan transformasional kepala sekolah, budaya sekolah, lingkungan sekolah, dan kinerja guru.

\section{PENDAHULUAN}

Pendidikan adalah aspek yang tidak bisa terlepas dari semua sendi kehidupan manusia. Baik pendidikan dalam arti makro maupun pendidikan dalamarti mikro, setiap orang akan mengalami proses pendidikan. Fenomena tersebut memberikan indikasi bahwa pendidikan 
memegang peranan dalam menyediakan sumber daya manusia yang berkualitas, bahkan sangat menentukan berhasil tidaknya pembangunan. Secara lebih arif dapat dikatakan bahwa pendidikan yang bermutu dapat menghasilkan kualitas pendidikan yang bermutu. Melalui pendidikan dapat dikembangkan juga kemampuan pribadi, daya pikir, dan tingkah laku yang lebih baik.

Dalam Standar nasional, pendidikan bertujuan menjamin mutu pendidikan nasional dalam rangka mencerdaskan kehidupan bangsa dan membentuk watak serta peradaban bangsa yang bermartabat. Untuk mencapai tujuan tersebut, Peraturan Pemerintah nomor 19 Tahun 2005 tentang Standar Nasional Pendidikan, menetapkan delapan Standar yang harus dipenuhi dalam melaksanakan pendidikan. Kedelapan standar yang dimaksud meliputi: standar isi, standar proses, standar kompetensi lulusan, standar pendidik dan tenaga kependidikan, standar sarana dan prasarana, standar pengelolaan, standar pembiayaan dan standar penilaian pendidikan. Salah satu standar yang dinilai langsung berkaitan dengan mutu lulusan yang diindikasikan oleh kompetensi lulusan adalah standar pendidik dan tenaga kependidikan. Ini berarti bahwa untuk dapat mencapai mutu lulusan yang diinginkan, mutu tenaga pendidik (guru), dan tenaga kependidikan (kepala sekolah, pengawas, laboran, pustakawan, tenaga administrasi, pesuruh) harus ditingkatkan. ${ }^{1}$

Di Indonesia, sekolah/madrasah harus bersungguh-sungguh dalam melaksanakan tugas dan fungsinya untuk mewujudkan tujuan nasional. Sebagaimana yang tercantum dalam Undang-undang RI No.20 Tahun2003 tentang Sistem Pendidikan Nasional beserta penjelasaannya BabII Pasal3 bahwa:

Pendidikan Nasional berfungsi mengembangkan kemampuan dan membentuk watak serta peradaban bangsa yang bermartabat dalam rangka mencerdaskan kehiupan bangsa, bertujuan untuk berkembangnya potensi peserta didik agar menjadimanusia yang beriman dan bertakwa kepada Tuhan Yang Maha Esa, berakhlak mulia, sehat, mandiri dan menjadi wargaNegara yang demokratis serta bertanggungjawab. ${ }^{2}$

Untuk mewujudkan tujuan di atasdibutuhkan peningkatan sumber daya manusia yang bermutu. Antara lain seorang Pemimpin Sekolah yang mampu menata sekolah dengan baik dan Tenaga Pendidik atau Guru yang profesional serta lingkungan sekolah yang baik dan

\footnotetext{
${ }^{1}$ Presiden Republik Indonesia. (2005). Peraturan Pemerintah tentang Standar Nasional Pendidikan.

2 DPR RI. (2003). UU Nomor 20 Tahun 2003 tentang Sistem Pendidikan Nasional.
} 
kondusif mendukung kinerja Guru meningkat yang pada gilirannya dapat meningkatkan prestasi anak didik menjadi meningkat. ${ }^{3}$

Masalah kepemimpinan selalu memberikan kesan yang menarik sebab suatu organisasi dapat berhasil atau tidaknya sebagian ditentukan oleh kualitas kepemimpinan. Sutisna menjelaskan kepemimpinan merupakan proses mempengaruhi kegiatan seseorang atau kelompok dalam usaha ke arah pencapaian tujuan dalam situasi tertentu. ${ }^{4}$ Sehingga dapat diartikan bahwa Kepemimpinan merupakan tindakan yang dilakukan olehi ndividu untuk mempengaruhi dan memberikan arah kepada individu atau kelompok lain dalam suatu organisasi tertentu untuk mencapai tujuan yang telah ditetapkan sebelumnya. Kepemimpinan adalah salah satu faktor utama dalam kehidupan berorganisasi yang memegang peranan kunci. Kepemimpinan seorang pemimpin berperan sebagai pengatur dalam proses kerja sama antara pemimpin dengan individu maupun pemimpin dengan kelompoknya.

Setiap kepala sekolah sebagai pemimpin organisasi perlu menguasai dan memiliki kemampuan untuk memotivasi bawahannya. Agar kepala sekolah dapat mempengaruhi bawahannya,maka harus memahami apa yang menjadi kebutuhan bawahannya. Keberhasilan pengelolaan sekolah sangat ditentukan oleh kegiatan pendayagunaan sumber daya manusia. Oleh karena itu kepala sekolah sebagai pemimpin dalam suatu organisasi hendaknya menyadari dan tanggap teknik-teknik untuk dapat memelihara prestasi dan kepuasan kerja guru antara lain dengan memberikan dorongan kepada guru agar dapat melaksanakan tugas mereka sesuai dengan aturan dan pengarahan.

Pemimpin mempengaruhi bawahan, tetapi bawahan juga mempunyai beberapa pengaruh terhadap pemimpin. Sumber pengaruh atau kewibawaan pada pemimpin menurut French dan Raven berasal dari legitimasi, memaksa, penghargaan, keahlian, dan penyesuaian (Legitimate, coercive, reward, expert, referent). Atau secara singkat pengaruh pemimpin terhadap bawahan pada dasarnya seperti yang dikemukakan oleh Amitai Etzione mengalir dari Position dan personal power (kedudukan dan kepribadian seseorang). ${ }^{5}$

Kepemimpinan yang efektif dan tidak efektif merupakan hal yang paling utama yang harus dipahami oleh seorang pemimpin (kepala sekolah) dalam memimpinsuatu organisasi

\footnotetext{
${ }^{3}$ Agus Sunarno. (2005). Pengaruh Motivasi Kerja, Kepemimpinan Kepala Sekolah dan Lingkungan Kerja Terhadap Kinerja Guru (Suatu Studi Berdasarkan Persepsi Guru SMK Negeri Kota Tegal) (s2). Universitas Muhammadiyah Surakarta. Diambil dari http://eprints.ums.ac.id/7006/.

4 Mulyasa, E. Manajemen Berbasis Sekolah: Konsep, Strategi dan Implementasi. (Bandung: Remaja Rosdakarya, 2002), hlm. 107.

5 Wahjosumidjo. Kepemimpinan Kepala Sekolah: Tinjauan Teoritk dan Permasalahanya. (Jakarta: Raja Grasindo Persada, 2010).
} 
atau kelompok. Dengan memahami gaya kepemimpinan akan dapat meningkatkan pemahaman seorang pemimpin (kepala sekolah) terhadap dirinya sendiri serta dapat mengetahui kelemahan maupun kelebihan potensi yang ada dalamdirinya dan dapat meningkatkan pemahaman tentang bagaimana seharusnya memperlakukan bawahannya.

Kepemimpinan seorang pemimpin (kepala sekolah) akan mampu membedakan antara suatu organisasi dengan organisasi lainnya. Gaya kepemimpinan yang di miliki oleh pemimpin (kepala sekolah) dalam memimpin suatu organisasi akan mempengaruhi kinerja dari pada guru itu.

Setiap kepala sekolah sebagai pemimpin tertinggi yang berada pada organisasi sekolah hendaknya memiliki bekal kemampuan, keahlian dan keterampilan dalam menjalankan lembaga yang dipimpinnya. Selain itu, kemampuan untuk mempengaruhi serta memotivasi bawahannya perlu untuk dimiliki guna untuk meningkatkankinerja bawahannya. Keberhasilan organisasi sekolah bukan hanya ditentukan olehpemimpinnya saja tetapi juga dapat didukung oleh pendayagunaan sumber daya manusia karena kelemahan yang dimiliki dari seorang pemimpin (kepala sekolah) bisa jadi terdapat pada kelebihan yang dimiliki oleh bawahannya (guru) itu sendiri.

Oleh sebab itu, salah satu tugas kepala sekolah adalah untuk bisa menciptakan guru profesional agar bisa bekerja sesuai dengan pengarahan yang diberikan. Lebih jauh kepala sekolah sebagai pimpinan, harus mengetahui kinerja guru-gurunya. Karena kinerja paling tidak sangat berkaitan dengan kepemimpinan organisasi sekolah dan juga kepentingan guru itu sendiri, oleh karena itu bagi sekolah dasar, hasil penilaian kinerja para guru sangat penting artinya dan peranannya dalam pengambilan keputusan tentang berbagai hal, seperti identifikasi kebutuhan program pendidikan dan pelatihan, rekrutmen, seleksi, penempatan, promosi dan berbagai aspek lain. Sedangkan bagi guru penilaian dapat berperan sebagai umpan balik tentang berbagai hal seperti kemampuan, kelebihan, kekurangan, dan potensi yang pada gilirannya bermanfaat untuk menentukan tujuan, jalur, rencana dan pengembangan kariernya. Sehingga secara berkala hendaknya mengadakan penilaian kinerja guru-gurunya.

Di samping itu, budaya sekolah menjadi unsur penting dalam pengembangan sekolah. Sekolah adalah lembaga yang dirancang untuk pengajaran siswa dibawah pengawasan guru. Setiap sekolah memiliki budayanya sendiri karenabudaya sekolah merupakan cerminan dari nilai, norma, aturan moral, dankebiasaan yang telah membentuk perilaku dan hubungan yang terjadi disekolah. Budaya sekolah menggambarkan suasana dan hubungan kerja antarasesama guru, guru dengan kepala sekolah, guru dengan tenaga kependidikan,dan Dinas di lingkungannya. Budaya sekolah merupakan wujud darilingkungan kerja yang kondusif 
sehingga membantu guru dan kepala sekolahuntuk melaksanakan pekerjaannya dengan efektif. $^{6}$ Penerapanbudaya sekolah akan memberikan petunjuk, warna/kesan, dan karakteristiksekolah yang akan memengaruhi kinerja guru.

Budaya sekolah penting untuk diterapkan secara terus-menerus karenaitu merupakan identitas sekolah. Budaya sekolah yang belum menunjukkankeberhasilan dan mampu bersaing dalam mencapai kualitas pendidikan perludilakukan perubahan. Perubahan budaya sekolah sangat penting karena duniaberubah dengan cepat, tuntutan masyarakat berubah, persaingan kemampuansumber daya manusia, peningkatan kualitas pendidikan yang terus menerusdan berkelanjutan.

Perubahan budaya sekolah dapat dimulai dari perilaku seorangpemimpin yang berupaya untuk mengejar mutu yang diinginkan setiapsekolah dan menumbuhkan komitmen guru terhadap perubahan sehinggamemengaruhi seluruh warga sekolah untuk menerapkan budaya sekolah yangtelah ditetapkan. Komitmen guru terhadap perubahan merupakan gagasanyang menjelaskan proses motivasi guru untuk menjadi bagian dari prosesperubahan sekolah. Unsur yang terlibat dalam penerapan komitmen guruterhadap perubahan, yaitu tujuan pribadi seorang guru untuk menciptakankualitas pendidikan, keyakinan akan kapasitas dan konteks, serta prosesrangsangan emosional untuk mencapai tujuan jangka panjang dalampelaksanaan pendidikan.

Dalam konteks lain, lingkungan sekolah juga merupakan variabel yang menarik dibicarakan dalam pengembangan Pendidikan. Lingkungan sekolah memegang peranan penting dalam menghasilkan kinerja yang maksimal. Lingkungan sekolah merupakan tempat di mana guru melakukan aktivitas setiap harinya yang kondusif akan memberikan rasa aman dan memungkinkan guru untuk dapat mengajar secara optimal. Lingkungan kerja dapat mempengaruhi emosi guru. Jika guru menyenangi lingkungan kerja di mana dia bekerja, maka guru tersebut akan betah di tempat kerjanya, melakukan aktivitas sehingga waktu kerja dipergunakan secara efektif. Lingkungan kerja itu mencakup hubungan kerja yang terbentuk antara sesama guru, guru dengan kepala sekolah, guru dan peserta didik dan guru dengan stage holder lainnya. Hubungan kerja yang baik di lingkungan kerja akan membawa

\footnotetext{
${ }^{6}$ Setiyati, S. (2014). Pengaruh Kepemimpinan Kepala Sekolah, Motivasi Kerja, dan Budaya Sekolah Terhadap Kinerja Guru. Jurnal Pendidikan Teknologi dan Kejuruan, 22(2), 200-206. https://doi.org/10.21831/jptk.v22i2.8931
} 
pengaruh yang baik untuk guru dalam proses pembelajaran. ${ }^{7}$ Dari pengaruh baik terhadap guru tersebut, maka dimungkinkan kinerja guru akan meningkat.

Guru mempunyai fungsi, peran, dan kedudukan yang sangat penting dalam dunia pendidikan. Tanpa guru, tentu saja tidak ada yang mendidik anak-anak agar menjadi generasi muda yang berpendidikan. Selain hal tersebut, guru adalah orang yang berhubungan dengan siswa secara langsung, sehingga guru yang memiliki kesempatan lebih banyak untuk mendidik siswa agar dapat menjadi generasi muda yang berpendidikan, bermoral baik, serta mencintai budaya Indonesia. Jika dibaratkan dalam dunia perfilman, guru ini adalah tokoh utamanya.

Jika pendidikan merupakan salah hal yang paling utama dalam pengembangan sumber daya manusia maka tenaga pendidik dan tenaga kependidikan tentunya memiliki tanggung jawab yang sangat besar dalam mengemban tugas ini. Sehingga standar mutu pendidik dan tenaga kependidikan perlu untuk ditingkatkan

Kinerja guru adalah kemampuan seorang guru dalam melaksanakan proses pembelajaran di kelas sesuai dengan tujuan yang telah ditetapkan. ${ }^{8}$ Dimana kemampuan tersebut telah mencakup beberapa aspek, di antaranya: perencanaan program belajar mengajar, pelaksanaan proses belajar mengajar, penciptaan dan pemeliharaan kelas yang optimal, pengendalian kondisi belajar yang optimal, serta penilaian hasil belajar. Kinerja tentu menjadi faktor yang sangat penting dalam menentukan kualitas kerja seseorang termasuk seorang guru.

Di samping itu, Kinerja guru adalah kemampuan seorang guru dalam melaksanakan proses pembelajaran di kelas sesuai dengan tujuan yang telah ditetapkan. Dimana kemampuan tersebut telah mencakup beberapa aspek, di antaranya: perencanaan program belajar mengajar, pelaksanaan proses belajar mengajar, penciptaan dan pemeliharaan kelas yang optimal, pengendalian kondisi belajar yang optimal, serta penilaian hasil belajar. Kinerja tentu menjadi faktor yang sangat penting dalam menentukan kualitas kerja seseorang termasuk seorang guru.

Kinerja guru merupakan seluruh usaha serta kemampuan seorang guru dalam melaksanakan proses pembelajaran untuk mencapai tujuan dari pendidikan. Adapun kinerja

\footnotetext{
${ }^{7}$ Siti Nurbaya, S., \& Hr, A. (2016). Pengaruh Kompetensi, Disiplin Kerja, dan Lingkungan Sekolah terhadap Kinerja Guru Sekolah Dasar di Kecamatan Wajo Kota Makassar. Competitiveness : Jurnal Manajemen dan Bisnis, 10(2), 46-60.

8 Sumarno. Pengaruh Kepemimpinan Kepala Sekolah dan Profesionalisme Guru Terhadap Kinerja Guru Sekolah Dasar Negeri di Kecamatan Paguyangan Kabupaten Brebes. (Semarang: Universitas Negeri Semarang, 2009), hlm. 20.
} 
guru meliputi seluruh kegiatan yang menyangkut tugas utama sebagai seorang guru serta pengembangan pribadi seorang guru. Tugas utama seorang guru dalam proses pembelajaran dapat dimulai dari merencanakan pembelajaran, melaksanakan, mengevaluasi, memberikan penilaian sampai dengan tindak lanjut dalam proses pembelajaran. Selain itu, seorang guru juga dituntut untuk dapat memiliki wawasan yang luas dalam ilmu kependidikan, pemahaman terhadap peserta didik serta mampu untuk mengembangkan potensi yang dimiliki oleh peserta didik.

Guru menjadi salah satu unsur sumber daya yang sangat menentukan keberhasilan dalam pendidikan di sekolah, karena guru merupakan unsur manusiawi yang sangat dekat dengan peserta didik dalam pendidikan sehari- hari di sekolah. Depdikbud menyatakan bahwa guru merupakan sumber daya manusia yang mampu mendayagunakan faktor-faktor lainnya sehingga tercipta proses belajar mengajar yang bermutu dan menjadi faktor utama yang menentukan mutu pendidikan.

Sebagai tenaga pendidik, guru menjadi faktor penentu dalam peningkatan mutu pendidikan di sekolah. Oleh karena itu, para pendidik (guru) harus dapat meningkatkan kinerja dalam melaksanakan tugas, karena pendidikan di masa yang akan datang menuntut keterampilan profesi pendidikan yang bermutu. Sehingga kinerja guru yang profesional dapat menjadi angin segar bagi keberhasilan dalam dunia pendidikan di masa yang akan datang. Untuk meningkatkan kinerja guru di sekolah pemberian berbagai jenis pelatihan dan pendidikan profesi kepada para guru tentu sangat dibutuhkan. Taufik menjelaskan ada dua faktor penting yang mempengaruhi kinerja guru di sekolah yaitu faktor kualifikasi standar guru dan relevansi antara bidang keahlian guru dengantugas mengajar. ${ }^{9}$

Kinerja penting untuk diteliti karena ukuran keberhasilan dari suatu organisasi atau sekolah dapat dilihat dari kinerja maupun pelaksanaan pekerjaannya, sehingga kemajuan suatu sekolah dapat dipengaruhi oleh kinerja guru-gurunya. Penilaian kinerja guru sebenarnya merupakan penilaian terhadap penampilan kerja guru itu sendiri terhadap taraf potensi kerja guru dalam upaya mengembangkan diri untuk kepentingan sekolah.

Dalam hal kinerja guru, agar kinerja guru dapat maksimal maka ketia harus mampu memaksimalkan faktor-faktor yang mampu mempengaruhi kinerja guru. Oleh karenanya peneliti akan mencoba meneliti beberapa faktor yang mempengaruhi kinerja guru. Disini peneliti memfokuskan pada kepemimpinan transformasional kepala sekolah, budaya sekolah, dan lingkungan sekolah di MI Islamiyah Wareng.

\footnotetext{
${ }^{9}$ Hadis, A., \& Nurhayati, B. Manajemen Mutu pendidikan. (Bandung: Alfabeta, 2010), hlm. 9.
} 
Berdasar pada pemaparan di atas, maka sangat penting untuk dilakukan penelitian yang lebih serius. Untuk itu, maka penelitian memiliki kegelisahan untuk melakukan penelitian ini, maka penulis mengambil judul penelitian "Pengaruh Kepemimpinan Transformasional Kepala Sekolah, Budaya Sekolah, dan Lingkungan Sekolah terhadap Kinerja Guru di MI Islamiyah Wareng,Butuh, Purworejo, Jawa Tengah”.

\section{KAJIAN LITERATUR}

\section{Kinerja Guru}

Kinerja guru adalah kemampuan seorang guru dalam melaksanakan proses pembelajaran di kelas sesuai dengan tujuan yang telah ditetapkan. ${ }^{10}$ Di mana kemampuan tersebut telah mencakup beberapa aspek, di antaranya: perencanaan program belajar mengajar, pelaksanaan proses belajar mengajar, penciptaan dan pemeliharaan kelas yang optimal, pengendalian kondisi belajar yang optimal, serta penilaian hasil belajar. Kinerja tentu menjadi faktor yang sangat penting dalam menentukan kualitas kerja seseorang termasuk seorang guru.

Riva'i mengemukakan bahwa aspek-aspek yang dapat dinilai dari kinerja guru dalam suatu organisasi di sekolah dikelompokkan menjadi tiga yaitu: (a) Kemampuan teknik yaitu kemampuan menggunakan pengetahuan, metode, teknik dan peralatan yang dipergunakan untuk melaksanakan tugas serta pengalaman dan pelatihan yang telah diperoleh; (b) kemampuan konseptual yaitu kemampuan untuk memahami kompleksitas organisasi dan penyesuaian bidang gerak dari unit-unit operasional; dan (c) kemampuan hubungan interpersonal yaitu kemampuan untuk bekerja sama dengan orang lain, membawa guru melakukan negosiasi. Guru dapat memperlihatkan kinerjanya apabila guru memiliki pengetahuan, keahlian, kemampuan dan karakteristik lain yang diperlukan. Dengan kata lain, seseorang yang memiliki pengetahuan, skill, kemampuan interpersonal, dan karakter yang baik akan menunjukkan kinerja yang tinggi, dan sebaliknya apabila seseorang memiliki pengetahuan, keterampilan, komunikasi interpersonal dan kepribadiannya tidak baik pastilah kinerjanya rendah. ${ }^{11}$

\footnotetext{
${ }^{10}$ Sumarno, Op.Cit.

${ }^{11}$ Siregar, Y. (2018). Pengaruh Gaya Kepemimpinan Kepala Sekolah terhadap Kinerja Guru Bimbingan dan Konseling di SMA Negeri Jakarta Timur. Teraputik: Jurnal Bimbingan dan Konseling, 1 (3), 232-238-238. https://doi.org/10.26539/1388.
} 
Melakukan pekerjaan tentunya terdapat pengaruh-pengaruh baik dari dalam diri sendiri maupun pengaruh dari luar yang dapat meningkatkan kualitas kerja, bahkan dapat menurunkan kualitas kerja. Perusahaan atau organisasi tempat bekerja tidak hanya berisi seorang saja, namun terdiri dari berbagai guru yang akan saling bekerja sama untuk mencapai tujuan yang telah ditetapkan. Menurut Martinis Yamin faktor-faktor yang mempengaruhi kinerja guru antara lain sebagai berikut:

a. Faktor personal atau individual, meliputi unsur pengetahuan, keterampilan, kemampuan, kepercayaan diri, motivasi, dan komitmen yang dimiliki oleh tiap individu tiap guru,

b. Faktor kepemimpinan, memiliki aspek kualitas manajer dan tim leader dalam memberikan dorongan, semangat, arahan dan dukungan kerja kepada guru,

c. Faktor tim meliputi dukungan dan semangat yang diberikan oleh rekan dalam satu tim, kepercayaan terhadap sesama anggota tim, kekompakan dan keratan anggota tim,

d. Faktor sistem, meliputi sistem kerja fasilitas kerja yang diberikan oleh pimpinan sekolah, proses organisasi (sekolah) dan kultur kerja dalam organisasi (sekolah),

e. Faktor kontekstual (situasional), meliputi tekanan dan perubahan lingkungan eksternal (sertifikasi guru) dan internal (motivasi kerja guru). ${ }^{12}$

Menurut Timpe, ada enam faktor eksternal yng menentukan tingkat kinerja seorang guru. Faktor penentu ini adalah lingkungan, perilaku manajemen, desain jabatan, penilaian kerja, umpan balik, dan administrasi pengupahan. ${ }^{13}$

Menurut Anwar Prabu Mangkunegara, faktor yang mendukung kinerja guru dapat digolongkan ke dalam dua macam yakni:

a. Faktor dari dalam diri sendiri (intern), adalah faktor yang berasal dari diri pekerja tersebut. Faktor intern ini contohnya adalah kecerdasan, keterampilan, kecakapan, bakat, kemampuan, minat, motif, kesehatan, kepribadian, cita-cita, dan tujuan dalam bekerja.

b. Faktor dari luar diri sendiri (ekstern), adalah faktor yang ditimbulkan dari luar diri pekerja. Faktor ekstern dapat berasal dari lingkungan keluarga, lingkungan kerja, komunikasi dengan kepala sekolah, sarana dan prasarana, kegiatan guru di kelas, kegiatan guru di sekolah. ${ }^{14}$

Faktor yang mempengaruhi kinerja guru banyak sekali, namun dari sekian banyaknya faktor, yang sangat berpengaruh terhadap kinerja guru yakni adalah faktor kepemimpinan. Hal ini juga dikemukakan oleh Wibowo, yang menyatakan bahwa kepemimpinan dan gaya kepemimpinan dalam organisasi sangat berperan dalam mempengaruhi kinerja guru, karena cara menjalin hubungan dengan pekerja, memberi penghargaan kepada pekerja yang

\footnotetext{
${ }^{12}$ Martinis Yamin \& Maisah. Standarisasi Kinerja Guru. (Jakarta: Gaung Persada Pers, 2010), hlm. 43.

13 A. Dale Timpe. The Art and Science Of Bussines Management Performance, terjemahan : Sofyan Cikmat. (Jakarta: Elex Media Computindo, 2000), hlm. IX.

${ }^{14}$ Anwar Prabu Mangkunegara. Evaluasi Kinerja SDM. (Bandung: Refika Aditama, 2012), hlm. 26-27.
} 
berprestasi, dan mengembangkan serta memberdayakan pekerjanya akan sangat mempengaruhi sumber daya manusia yang menjadi bawahannya. ${ }^{15}$

Di samping itu, dibutuhkan indikator dalam menilai kinerja guru. Indikator kinerja merupakan sesuatu yang akan dihitung dan diukur. Indikator yang dinilai dalam kinerja guru banyak sekali, baik yang berkaitan langsung dengan kegiatan pembelajaran maupun sebagai penunjang kegiatan pembelajaran. Tugas utama seorang guru adalah mendidik, mengajar, membimbing, mengarahkan, melatih, menilai, dan mengevaluasi peserta didik. Sedangkan tugas tambahan guru adalah tugas yang tidak berkaitan langsung dengan kegiatan pembelajaran, misalnya saja menjadi wali kelas, menjadi ketua prodi, menjadi kepala laboratorium atau ruang praktik, menjadi kepala sekolah, dan lain sebagainya.

Dari pemaparan di atas dapat disimpulkan bahwa kinerja guru dalam penelitian ini adalah hasil yang dicapai oleh guru dalam melaksanakan tugas-tugas pembelajaran yang dibebankan kepadanya yang didasarkan atas kecakapan, pengalaman dan kesungguhan serta waktu dengan output yang dihasilkan tercermin baik kuantitas maupun kualitasnya. Untuk melihat kinerja diukur dengan melalui kegiatan perencanaan pembelajaran, pelaksanaan pembelajaran, pelaksanaan penilaian pembelajaran, tindak lanjut hasil penilaian.

\section{Kepemimpinan Transformasional Kepala Sekolah}

Menurut Sudarwan Danim, kepemimpinan transformasional adalah kemampuan sesorang pemimpin dalam bekerja dengan dan/melalui orang lain untuk mentransformasikan, secara optimal sumber daya organisasi dalam rangka mencapai tujuan yang bermakna sesuai dengan target capaian yang telah ditetapkan. ${ }^{16}$ Sedangkan menurut Bass, kepemimpinan transformasional adalah suatu keadaan dimana para pengikut dari seorang pemimpin transformasional merasa adanya kepercayaan, kekaguman, kesetiaan, dan hormat terhadap pemimpin tersebut, dan mereka termotivasi untuk melakukan lebih dari pada yang awalnya diharapkan mereka. ${ }^{17}$

Menurut Burns, kepemimpinan transformasional dicirikan sebagai pemimpin yang berfokus pada pencapaian perubahan nilai-nilai, kepercayaan, sikap, perilaku, emosional, dan kebutuhan bawahan menuju perubahan yang lebih baik di masa depan. ${ }^{18}$ Seorang pemimpin berkewajiban juga untuk melakukan kegiatan pengendaliam, agar dalam usahanya

\footnotetext{
${ }^{15}$ Wibowo. Manajemen Kinerja. (Jakarta: Raja Grafindo Persada, 2011), hlm. 80.

${ }^{16}$ Sudarwan Danim. Visi Baru Manajemen Sekolah dari Unit Birokrasi ke Lembaga Akademik. (Jakarta: Bumi Aksara, 2004), hlm. 54.

${ }^{17}$ Yukl, G.A. Leadership in Organization. (7 $7^{\text {th }}$ ed.). (Upper Saddle River: Prentice Hall, 2010), hlm. 313.

${ }^{18}$ Safaria. Kepemimpinan. Edisi Pertama. (Yogyakarta: Graha Ilmu, 2004), hlm. 62.
} 
memengaruhi pikiran, perasaan, sikap dan perilaku anggota organisasi, selalu terarah pada tujuan organisasi. Adapun karakteristik kepemimpinan transformasional menurut Bass adalah sebagai berikut:

\section{a. Idealized influence(or charismatic influence)}

Idealized influence mempunyai makna bahwa seorang pemimpin transformasional harus kharisma yang mampu "menyihir" bawahan untuk bereaksi mengikuti pimpinan. Dalam bentuk konkrit, kharisma ini ditunjukkan melalui perilaku pemahaman terhadap visi dan misi orgaisasi, mempunyai pendirian yang kukuh, komitmen dan konsisten terhadap setiap keputusan yang telah diambil, dan menghargai bawahan. Dengan kata lain, pemimpin transformasional menjadi rale model yang dikagumi, dan dihargai, dan diikuti oleh bawahannya.

\section{b. Inspirational motivation}

Inspirational motivation berarti karakter sorang pemipin yang mampu menerapkan standar yang tinggi akan teteapi sekaligus mampu mendorong bawahan untuk mencapai standar tersebut. Karakter seperti ini mampu membangkitkan optimisme dan antusiasme yang tinggi dari para bawahan. Dengan kata lain, pemimpin transformasional senantiasa memberikan inspirasi dan memotivasi bawahannya.

\section{c. Intellectual stimulation}

Intellectual stimulation karakter seorang pemimpin transformasional yang mampu mendorong bawahannya untuk menyelesaikan permasalahan dengan cermat dan rasional. Selain itu, karakter ini mendorong para bawahan untuk menemukan cara baru yang lebih efektif dalam menyelesaikan masalah. Dengan kata lain, pemimpin transformasional mampu mendorong(menstimulasi) bawahan untuk selalu kreatif dan inovatif.

\section{d. Individualized consideran}

Individualized consideran berati karakter seorang pemimpin yang mampu memahami perbedaan individual para bawahannya. Dalam hal ini, pemimpin transformasional mau dan mampu untuk mendengar aspirasi, medidik, dan melatih bawahan. Selain itu, seorang pemimpin transformasional mampu melihat potensi prestasi dan kebutuhan berkembang para bawahan serta memfasilitasinya. Dengan kata lain, pemimpin transformasional mampu memahami dan menghargai bawahan berdasarkan 
kebutuhan bawahan dan memperhatikan keinginan berprestasi dan berkembang para bawahan. ${ }^{19}$

Berdasarkan hasil kajian literatur yang dilakukan, Northouse menyimpulkan bahwa seseorang yang dapat menampilkan kepemimpinan transformasional ternyata dapat lebih menunjukkan sebagai seorang pemimpin yang efektif dengan hasil kerja yang lebih baik. ${ }^{20}$ Oleh karena itu, merupakan hal yang amat menguntungkan jika para kepala sekolah dapat menerapkan kepemimpinan transformasional di sekolahnya.

Secara sederhana kepemimpinan transformasional kepala sekolah dapat diartikan sebagai proses yang dilakukan kepala sekolah untuk merubah dan mentransformasikan pada bawhannya agar mau berubah dan meningkatkan dirinya, yang didalamnya melibatkan motif dan pemenuhan kebutuhan serta penghargaan terhadap para bawahan tersebut. Seorang kepala sekolah harus mempunyai empat faktor untuk menuju kepemimpinan tranformasional, yang dikenal sebutan $4 \mathrm{I}$, yaitu : idealized influence, inspirational motivation, intellectual stimulation, dan individual consideration.

\section{Budaya Sekolah}

Komariah dan Triatna menyatakan bahwa budaya sekolah merupakan aspek penting dalam sistem pendidikan yang memberikan perasaan senang atau sedih, suka atau duka, bergairah atau lesu, bangga atau kecewa, dan segala yang melibatkan perasaan seseorang. Budaya sekolah dapat membentuk seseorang patuh terhadap peraturan dan menciptakan kebiasaan baru secara disiplin sesuai peraturan yang ditegakkan sekolah. ${ }^{21}$ Hal ini berarti bahwa budaya merupakan atribut atau peraturan-peraturan yang dirancang sesuai dengan keinginan bersama untuk dipatuhi.

Engels mengemukakan budaya sekolah adalah asumsi dasar, norma dan nilai-nilai, dan artefak budaya yang diyakini bersama warga sekolah, yang mempengaruhi fungsi warga sekolah saat berada di sekolah, dan memainkan peran penting dalam meningkatkan efektivitas sekolah. ${ }^{22}$

Zamroni memberikan batasan bahwa budaya sekolah adalah pola nilai-nilai, normanorma, sikap, ritual, mitos, dan kebiasaan-kebiasaan yang terbentuk dalam perjalanan

\footnotetext{
${ }^{19}$ Bass, B.M. \& Avolio, B.J. (1990). Developing Transformational Leadership - 1992 and Beyond. Journal of European Industrial Training. Vol.14 No.5, Pages 21-27.

${ }^{20}$ Northouse, P. G. Leadership: Theory and practice. (4 ${ }^{\text {th }}$ ed.). (Thousand Oaks: Sage Publication, 2007).

${ }^{21}$ Aan Komariah \& Cepy Triatna. Visionary Leadership Menuju Sekolah Efektif. (Jakarta: Bumi Aksara, 2005).

${ }^{22}$ Engels, N., Hotton, G., Devos, G., Bouckenooghe, D., \& Aelterman, A. (2008). Principals in Schools with a Positive School Culture. Educational Studies, 34(3), 159-174.
} 
panjang sekolah, dimana budaya sekolah tersebut dipegang bersama oleh kepala sekolah, guru, staf, maupun siswa, sebagai dasar mereka dalam memahami dan memecahkan berbagai persoalan yang muncul disekolah. ${ }^{23}$ Konsep tersebut menekankan pada unsur-unsur yang terdapat di dalam budaya sekolah yang dijadikan sebagai sistem nilai seluruh anggota komunitas sekolah.

Berdasar dari definisi tersebut maka dapat ditarik kesimpulan bahwa budaya sekolah adalah suatu bagian yang penting dalam sistem pendidikan karenahal itu dapat mempengaruhi perilaku warga sekolah sesuai dengan asumsidasar, nilai-nilai, norma, dan kepercayaan yang telah ditegakkan sekolahserta membangun prestasi dari warga sekolah sehingga membentukkualitas pendidikan di sekolah.

Sekolah dengan kultur yang positif mempunyai serangkaian yang mendukung perkembangan profesi guru, rasa tanggung jawab pada pembelajaran siswa, atmosfer yang positif, dan kepedulian yang tinggi terhadap sesama. Sebaliknya dalam lingkungan sekolah dengan budaya negatif hubungan antara guru sering terjadi konflik, guru tidak percaya jika siswa mempunyai kemampuan untuk berhasil, dan biasanya mempunyai sikap negatif seperti kurang memiliki informasi yang jelas tentang tujuan, norma yang digunakan untuk kemajuan, tidak mendukung kolaborasi, dan sering terjadi hubungan antar warga sekolah yang tidak ramah. Untuk mengubah budaya yang beracun tersebut menurut Peterson perlu dilakukan penilaian terhadap staf dengan norma-norma dan nilai-nilai yang ditekankan pada kultur dan kemudian sebagai kelompok yang aktif bekerja sama berusaha mengubahnya untuk bisa mempunyai kultur yang positif dan mendukung. ${ }^{24}$

Budaya sekolah berdampak pada kinerja guru. ${ }^{25}$ Kepribadian seseorang pada hakikatnya ditentukan oleh nilai-nilai yang terintegrasi dalam dirinya sehingga mendorong untuk berbuat atau melakukan sesuatu. Tindakan atau perbuatan seseorang mencerminkan nilai-nilai yang diakui dan dianutnya. Nilai-nilai mengarahkan jalan hidup seseorang. Seseorang bertindak berdasarkan nilai yang diyakini dan selalu diulang sehingga menjadi kaidah hidupnya, sehingga kinerja guru sangat ditentukan oleh nilai-nilai budaya yang ada di lingkungan sekitar. Dari pemaparan diatas dapat disimpulkan bahwa budaya sekolah dalam penelitian ini merupakan artefak budaya, nilai, kepercayaan dan asumsi dasar.

\footnotetext{
${ }^{23}$ Zamroni. Paradigma Pendidikan Masa Depan. (Yogyakarta: Bayu Indra Grafika, 2000), hlm. 149.

24 Peterson. (2002). Reculturing Schools. Diambil 14 Agustus 2011, dari http://smhp.psych.ucla.edu/qf/burnout_qt/reculturingschools.pdf

${ }^{25}$ Ekosusilo, M., \& Soepardjo, S. (2014). Faktor Dominan yang Memengaruhi Motivasi Kerja, Kinerja, dan Kepuasan Kerja Guru SMA. Jurnal Ilmu Pendidikan, 20(2). https://doi.org/10.17977/jip.v20i2.4609.
} 


\section{Lingkungan Sekolah}

Menurut Munib, "Lingkungan secara umum diartikan sebagaikesatuan dengan semua benda, daya, keadaan, dan makhluk hidup, termasuk manusia dan perilakunya, yang mempengaruhi kelangsungan peri kehidupan dan kesejahteraan manusia serta makhluk hidup lainya."26 Lingkungan pendidikan pada hakikatnya merupakan sesuatu yang ada diluar individu maupun di dalam individu. ${ }^{27}$ Lebih lanjut Siswoyo menyatakan bahwa "Perguruan atau sekolah atau balai wiyata adalah lingkungan pendidikanyang mengembangkan dan meneruskan pendidikan anak menjadi warga negara yang cerdas, terampil dan bertingkah laku baik". Dari pengertian diatas dapatdisimpulkan bahwa lingkungan pendidikan dapat diartikan sebagai lingkungantempat berlangsungnya proses pendidikan.

Dengan demikian, pengertian di atas dapat dinyatakan bahwa lingkungan adalah kondisi hubungan timbal balik individu dengan individu, individu dengan kelompok dan kelompok dengan kelompok yang bersifat dinamis sehingga membentuk perkembangan individu-individu di dalamnya. Menurut Timpe, ada enam faktor eksternal yng menentukan tingkat kinerja seorang guru. Faktor penentu ini adalah lingkungan, perilaku manajemen, desain jabatan, penilaian kerja, umpan balik, dan administrasi pengupahan. ${ }^{28}$

Pernyataan bahwa kinerja dapat dipengaruhi oleh lingkungan kerja ditegaskan kembali oleh Timpe, bahwa lingkungan kerja yang menyenangkan menjadi kunci pendorong bagi para guru untuk menghasilkan kinerja puncak. ${ }^{29}$ Lingkungan sekolah turut mempengaruhi tingkat keberhasilan belajar siswa. $^{30}$ Slameto menerangkan bahwa faktor sekolah yang mempengaruhi belajar mencakup metode mengajar, kurikulum, relasi guru dengan siswa, relasisiswa dengan siswa, disiplin sekolah, alat pelajaran, waktu sekolah, standarpelajaran diatas ukuran, keadaan gedung, metode belajar, dan tugas rumah. ${ }^{31}$

Sekolah adalah lembaga pendidikan yang melaksanakan pembinaan pendidikan dan pengajaran dengan sengaja, teratur, dan terencana. ${ }^{32}$ Di lingkungan sekolah anak

${ }^{26}$ Oktaviana, I. (2015). Pengaruh Lingkungan Sekolah Terhadap Motivasi Belajar Siswa Kelas V Sekolah Dasar di Daerah Binaan I Kecamatan Limpung Kabupaten Batang (Other). Universitas Negeri Semarang. Diambil dari https://lib.unnes.ac.id/21074/

${ }^{27}$ Dwi Siswoyo. Ilmu Pendidikan (1 ed.). (Yogyakarta: UNY Press, 2011), hlm. 139-140.

${ }^{28}$ A. Dale Rimpe, Op. Cit.

${ }^{29} \mathrm{Ibid}, \mathrm{hlm} .3$.

${ }^{30}$ Slameto. Belajar dan Faktor-faktor yang Mempengaruhinya. (Jakarta: Rineka Cipta, 2003), hlm. 64.

31 Ibid.

32 Darodjat, Z. Pendidikan islam dalam Keluarga dan Sekolah. (Bandung: Ruhama, 1995). 
mendapatkan berbagai informasi tentang ilmu pengetahuan serta keterampilan yang diperlukan dalam kehidupannya.

Lingkungan Sekolah merupakan lembaga pendidikan formal, teratur, sistematis, bertingkat di mana ditempat inilah kegiatan pembelajaran berlangsung guna mengembangkan potensinya, baik yang menyangkut aspek moral, spiritual, intelektual, maupun sosial. Lingkungan sekolah dapat mempengaruhi perkembangan seorang anak dalam proses belajar di sekolah dan berpengaruh pada prestasi belajar yang diraih oleh siswa itu sendiri. Indikator dalam penelitian ini merujuk pada faktor lingkungan sekolah yaitu: (a) Kurikulum; (b) Relasi guru dengan siswa; (c) Relasi antar siswa; (d) Disiplin sekolah; (e) Keadaan gedung; (f) Tugas rumah. ${ }^{33}$

Dari pemaparan diatas dapat disimpulkan bahwa lingkungan sekolah dalam penelitian ini meliputi kurikulum, relasi guru dengan guru, relasi guru dengan siswa, disiplin sekolah, keadaan gedung, dan alat pembelajaran.

\section{METODE PENELITIAN}

Penelitian ini menggunakan pendekatan kuantitatif korelasional. Waktu penelitian adalah antara bulan Januari sampai dengan bulan April 2019, dan tempat penelitian adalah di MI Islamiyah Wareng, Kecamatan Butuh, Kabupaten Purworejo, Jawa Tengah. Dalam penelitian ini populasinya adalah guru-guru yang ada di MI Islamiyah Wareng, yang berjumlah 12 orang dan semuanya dijadikan sampel penelitian.

Teknik pengumpulan data menggunakan teknik kuisioner atau angket yang berisi sejumlah pertanyaan tertulis yang digunakan untuk memperoleh informasi dari responden, yaitu mengenai: kepemimpinan transformasional kepala sekolah, budaya sekolah, lingkungan sekolah, dan kinerja guru. Sedangkan penyusunan instrumen dalam penelitian ini dilakukan dengan beberapa tahapan, yaitu: (1) menentukan variabel penelitian; (2) menyusun indikator variabel penelitian; (3) menyusun kisi-kisi instrumen; (4) melakukan uji coba instrumen; dan (5) melakukan pengujian validitas dan reliabilitas instrumen.

Sebelum melakukan analisis data, terlebih dahulu dilakukan uji persyaratan analisis yaitu pengujian linearitas data, normalitas data, autokorelasi data, dan multikolinieritas data. Selanjutnya, dilakukan analisis regresi sederhana dan analisis regresi ganda.

\section{HASIL PENELITIAN DAN PEMBAHASAN}

${ }^{33}$ Slameto, Op.Cit. 


\section{Pengaruh Kepemimpinan Transformasional Kepala Sekolah terhadap Kinerja Guru MI Islamiyah Wareng, Butuh, Purworejo, Jawa Tengah}

Kepemimpinan transformasional kepala sekolah dapat diartikan sebagai proses yang dilakukan kepala sekolah untuk merubah dan mentransformasikan pada bawahannya agar mau berubah dan meningkatkan dirinya, yang didalamnya melibatkan motif dan pemenuhan kebutuhan serta penghargaan terhadap para bawahan tersebut.

Hasil analisis menunjukkan bahwa kepemimpinan transformasional kepala sekolah memiliki korelasi yang positif dengan kinerja guru. Hal tersebut terbukti dari nilai r sebesar 0,054. Positif artinya searah, maksudnya semakin tinggi kepemimpinan transformasional kepala sekolah, maka semakin tinggi kinerja guru. Selanjutnya, untuk menguji apakah satu variabel independen $\left(\mathrm{X}_{1}\right)$ secara parsial mempunyai pengaruh terhadap variabel dependen (Y), maka digunakan Uji t. Berdasarkan hasil analisis, diketahui bahwa nilai Sig $=0,866>\alpha$ $=0,05$, maka Ho diterima dan Ha ditolak. Dengan demikian, hipotesis pertama yang dinyatakan "Terdapat Pengaruh yang signifikan antara Kepemimpinan Transformasional Kepala Sekolah terhadap Kinerja Guru di MI Islamiyah Wareng, Butuh, Purworejo, Jawa Tengah" adalah tidak terbukti kebenarannya. Adapun $r^{2}$ (r square atau korelasi koefisien) sebesar 0,03\% menunjukkan kontribusi yang disumbangkan $\mathrm{X}_{1}$ kepada $\mathrm{Y}$.

Dengan demikian, maka hasil temuan penelitian ini tidak sejalan dengan teorinya Tobroni, yang mengemukakan bahwa, "kepala sekolah merupakan pemimpin dan salah satu agen perubahan sekolah yang terpenting." 34 Selanjutnya juga tidak sesuai dengan teorinya Supriadi yang mengemukakan bahwa "Erat hubungannya antara mutu kepala sekolah dengan berbagai aspek kehidupan” ${ }^{35}$, dalam hal ini termasuk kinerja guru.

Hasil penelitian ini tidak sesuai atau tidak sejalan dengan teorinya Northouse, yang menyimpulkan bahwa "seseorang yang dapat menampilkan kepemimpinan transformasional ternyata dapat lebih menunjukkan sebagai seorang pemimpin yang efektif dengan hasil kerja yang lebih baik". ${ }^{36}$ Hal tersebut karena kepemimpinan transformasional kepala sekolah memang memiliki korelasi dan pengaruh yang positif dengan kinerja guru MI Islamiyah Wareng Butuh Purworejo Jawa Tengan, namun demikian tidak signfikan.

\section{Pengaruh Kompetensi Budaya Sekolah terhadap Kinerja Guru MI Islamiyah Wareng, Butuh, Purworejo, Jawa Tengah}

\footnotetext{
${ }^{34}$ Tobroni. Pendidikan Islam, (Malang: UMM Press, 2008), hlm. 165.

${ }^{35}$ Mulyasa, E. Menjadi Kepala Sekolah Profesional. (Bandung: Remaja Rosdakarya, 2013), hlm. 24.

${ }^{36}$ Northouse, Op.Cit.
} 
Budaya sekolah adalah suatu bagian yang penting dalam sistem pendidikan karena hal itu dapat mempengaruhi perilaku warga sekolah sesuai dengan asumsi dasar, nilai-nilai, norma, dan kepercayaan yang telah ditegakkan sekolah serta membangun prestasi dari warga sekolah sehingga membentuk kualitas pendidikan di sekolah.

Hasil analisis menunjukkan bahwa budaya sekolah memiliki korelasi yang positif dengan kinerja guru. Hal tersebut terbukti dari nilai r sebesar 0,709. Positif artinya searah, maksudnya semakin tinggi budaya sekolah, maka semakin tinggi kinerja guru. Selanjutnya, untuk menguji apakah satu variabel independen $\left(\mathrm{X}_{2}\right)$ secara parsial mempunyai pengaruh terhadap variabel dependen (Y), maka digunakan Uji t. Berdasarkan hasil analisis, diketahui bahwa nilai Sig $=0,01<\alpha=0,05$, maka Ho ditolak dan Ha diterima. Dengan demikian, hipotesis kedua yang dinyatakan "Terdapat Pengaruh yang signifikan antara Budaya Sekolah terhadap Kinerja Guru di MI Islamiyah Wareng, Butuh, Purworejo, Jawa Tengah" adalah terbukti kebenarannya. Adapun $\mathrm{r}^{2}$ ( $\mathrm{r}$ square atau korelasi koefisien) sebesar 50,3\% menunjukkan kontribusi yang disumbangkan $\mathrm{X}_{2}$ kepada $\mathrm{Y}$.

Budaya sekolah memang memiliki korelasi dan pengaruh yang positif dengan kinerja guru MI Islamiyah Wareng Butuh Purworejo Jawa Tengan, namun demikian tidak signfikan. Dengan demikian, maka hasil temuan penelitian ini menguatkan teorinya Zubaidah, yang menunjukkan bahwa "budaya sekolah memiliki dampak pada mutu pendidikan."37 Selanjutnya juga sesuai teorinya Ekosusilo \& Soepardjo, yang mengemukakan bahwa, "budaya sekolah berdampak pada kinerja guru". ${ }^{38}$

\section{Pengaruh Lingkungan Sekolah terhadap Kinerja Guru MI Islamiyah Wareng, Butuh, Purworejo, Jawa Tengah}

Lingkungan sekolah adalah kesatuan semua benda, daya, keadaan, dan makhluk hidup, termasuk manusi dan perilakunya, yang mempengaruhi kelangsungan dari proses pendidikan. Hasil analisis menunjukkan bahwa motivasi kerja memiliki korelasi yang positif dengan kinerja guru. Hal tersebut terbukti dari nilai $\mathrm{r}$ sebesar 0,425. Positif artinya searah, maksudnya semakin tinggi lingkungan, maka semakin tinggi kinerja guru. Selanjutnya, untuk menguji apakah satu variabel independen $\left(\mathrm{X}_{3}\right)$ secara parsial mempunyai pengaruh terhadap variabel dependen (Y), maka digunakan Uji t. Berdasarkan hasil analisis, diketahui bahwa nilai Sig $=0,169>\alpha=0,05$, maka Ho diterima dan Ha ditolak. Dengan demikian, hipotesis

\footnotetext{
37 Zubaidah, S. (2015). Pengaruh Budaya Sekolah Dan Motivasi Kerja Guru Terhadap Mutu Pendidikan di SMK N 1 Pabelan. Prosiding Seminar Nasional Pendidikan.

${ }^{38}$ Ekosusilo, M., \& Soepardjo, S., Op.Cit.
} 
ketiga yang dinyatakan "Terdapat Pengaruh yang signifikan antara Lingkungan Sekolah terhadap Kinerja Guru di MI Islamiyah Wareng, Butuh, Purworejo, Jawa Tengah” adalah tidak terbukti kebenarannya. Adapun $\mathrm{r}^{2}$ ( $\mathrm{r}$ square atau korelasi koefisien) sebesar 18,0\% menunjukkan kontribusi yang disumbangkan $\mathrm{X}_{3}$ kepada $\mathrm{Y}$.

Dengan demikian, maka hasil temuan penelitian ini tidak sesuai dengan teorinya Timpe, yang menyatakan bahwa, "lingkungan kerja yang menyenangkan menjadi kunci pendorong bagi para guru untuk menghasilkan kinerja puncak." ${ }^{39}$ Selanjutnya juga tidak sesuai teorinya Slameto, yang menyatakan bahwa, "lingkungan sekolah turut mempengaruhi tingkat keberhasilan belajar siswa." 40 Lingkungan sekolah memang memiliki korelasi dan pengaruh yang positif dengan kinerja guru MI Islamiyah Wareng Butuh Purworejo Jawa Tengan, namun demikian tidak signfikan.

\section{Pengaruh Kepemimpinan Transformasional Kepala Sekolah, Budaya Sekolah, dan}

Lingkungan Sekolah secara bersama-sama terhadap Kinerja Guru MI Islamiyah Wareng, Butuh, Purworejo, Jawa Tengah

Kepemimpinan transformasional kepala sekolah, budaya sekolah, dan lingkungan sekolah secara bersama-sama memiliki korelasi positif dengan kinerja guru. Hal tesebut terbukti dari nilai $\mathrm{R}$ sebesar 0,720 . Positif artinya searah, maksudnya semakin tinggi kepemimpinan kepala sekolah, kompetensi pedagogik, dan motivasi kerja, maka semakin tinggi kinerja guru. Selanjutnya, untuk menguji apakah semua variabel independen $\left(\mathrm{X}_{1}, \mathrm{X}_{2}, \mathrm{X}_{3}\right)$ secara bersama-sama memiliki pengaruh yang signifikan terhadap variabel dependen (Y), maka digunakan Uji F.

Berdasarkan hasil Uji F, diketahui bahwa $\mathrm{F}_{\text {hitung }}=2,878<\mathrm{F}_{\text {tabel }}=4,96$, maka Ho diterima dan Ha ditolak. Selanjutnya, nilai Sig $=0,103>\alpha=0,05$, maka Ho diterima dan Ha ditolak. Dengan demikian, hipotesis keempat yang dinyatakan "Terdapat Pengaruh yang signifikan antara Kepemimpinan Kepala Sekolah, Budaya Sekolah dan Lingkungan Sekolah secara simultan terhadap Kinerja Guru di MI Islamiyah Wareng, Butuh, Purworejo, Jawa Tengah" adalah tidak terbukti kebenarannya. Adapun $\mathrm{R}^{2}$ (r square atau korelasi koefisien) sebesar $51,9 \%$ menunjukkan kontribusi yang disumbangkan $\mathrm{X}_{1}, \mathrm{X}_{2}, \mathrm{X}_{3}$ secara bersama-sama kepada Y.

Dengan demikian, hasil temuan penelitian ini secara khusus tidak sesuai dengan teorinya Tobroni, Supriadi (Mulyasa), Northouse, Zubaidah, Ekosusilo \& Soepardjo, Timpe,

\footnotetext{
${ }^{39}$ A. Dale Rimpe, Op. Cit.

${ }^{40}$ Slameto, Op.Cit.
} 
Slameto sebagaimana telah dikemukakan di depan. Hal tesebut karena Kepemimpinan transformasional kepala sekolah, budaya sekolah, dan lingkungan sekolah secara bersamasama memang memiliki korelasi dan pengaruh yang positif dengan kinerja guru MI Islamiyah Wareng Butuh Purworejo Jawa Tengan, namun demikian tidak signfikan.

\section{KESIMPULAN}

Berdasarkan hasil penelitian dan pembahasan yang telah dipaparkan, maka dapat ditulis kesimpulan sebagai berikut:

1. Kepemimpinan Transformasional Kepala Sekolah memiliki pengaruh yang tidak signifikan terhadap Kinerja Guru MI Islamiyah Wareng Butuh Purworejo Jawa Tengah, terbukti dari nilai Sig $=0,866>\alpha=0,05$. Adapun nilai koefisien korelasi $\left(r^{2}\right)=0,003$ atau hanya berkontribusi sebesar $0,3 \%$.

2. Budaya Sekolah memiliki pengaruh yang signifikan terhadap Kinerja Guru MI Islamiyah Wareng Butuh Purworejo Jawa Tengah, terbukti dari nilai Sig $=0,01<\alpha=0,05$. Adapun nilai koefisien korelasi $\left(\mathrm{r}^{2}\right)=0,503$ atau berkontribusi sebesar 50,3\%.

3. Lingkungan Sekolah memiliki pengaruh yang tidak signifikan terhadap Kinerja Guru MI Islamiyah Wareng Butuh Purworejo Jawa Tengah, terbukti dari nilai Sig $=0,169>\alpha=$ 0,05 . Adapun nilai koefisien korelasi $\left(\mathrm{r}^{2}\right)=0,180$ atau hanya berkontribusi sebesar $18,0 \%$.

4. Kepemimpinan Transformasional Kepala Sekolah, Budaya Sekolah, dan Lingkungan Sekolah secara bersama-sama memiliki pengaruh yang tidak signifikan terhadap Kinerja Guru MI Islamiyah Wareng Butuh Purworejo Jawa Tengah, terbukti dari nilai Sig = 0,103 $>\alpha=0,05$. Adapun nilai koefisien korelasi $\left(\mathrm{R}^{2}\right)=0,519$ atau berkontribusi sebesar $51,9 \%$.

\section{DAFTAR PUSTAKA}

Aan Komariah \& Cepy Triatna. (2005). Visionary Leadership Menuju Sekolah Efektif. Jakarta: Bumi Aksara.

A. Dale Timpe. (2000). The Art and Science Of Bussines Management Performance, terjemahan : Sofyan Cikmat. Jakarta: Elex Media Computindo.

Agus Sunarno. (2005). Pengaruh Motivasi Kerja, Kepemimpinan Kepala Sekolah dan Lingkungan Kerja Terhadap Kinerja Guru (Suatu Studi Berdasarkan Persepsi Guru SMK Negeri Kota Tegal) (s2). Universitas Muhammadiyah Surakarta. Diambil dari http://eprints.ums.ac.id/7006/.

Anwar Prabu Mangkunegara. (2012). Evaluasi Kinerja SDM. Bandung: Refika Aditama.

Bass, B.M. \& Avolio, B.J. (1990). Developing Transformational Leadership - 1992 and Beyond. Journal of European Industrial Training. Vol.14 No.5, Pages 21-27. 
Darodjat, Z. (1995). Pendidikan islam dalam Keluarga dan Sekolah. Bandung: Ruhama.

DPR RI. (2003). UU Nomor 20 Tahun 2003 tentang Sistem Pendidikan Nasional.

Dwi Siswoyo. (2011). Ilmu Pendidikan (1 ed.). Yogyakarta: UNY Press.

Ekosusilo, M., \& Soepardjo, S. (2014). Faktor Dominan yang Memengaruhi Motivasi Kerja, Kinerja, dan Kepuasan Kerja Guru SMA. Jurnal Ilmu Pendidikan, 20(2). https://doi.org/10.17977/jip.v20i2.4609.

Engels, N., Hotton, G., Devos, G., Bouckenooghe, D., \& Aelterman, A. (2008). Principals in Schools with a Positive School Culture. Educational Studies, 34(3), 159-174.

Hadis, A., \& Nurhayati, B. (2010). Manajemen Mutu pendidikan. Bandung: Alfabeta.

Martinis Yamin \& Maisah. (2010). Standarisasi Kinerja Guru. Jakarta: Gaung Persada Pers.

Mulyasa, E. (2002). Manajemen Berbasis Sekolah: Konsep, Strategi dan Implementasi. Bandung: Remaja Rosdakarya.

Mulyasa, E. (2013). Menjadi Kepala Sekolah Profesional. Bandung: Remaja Rosdakarya.

Northouse, P. G. (2007). Leadership: Theory and practice. (4 ${ }^{\text {th }}$ ed.). Thousand Oaks: Sage Publication.

Oktaviana, I. (2015). Pengaruh Lingkungan Sekolah Terhadap Motivasi Belajar Siswa Kelas $V$ Sekolah Dasar di Daerah Binaan I Kecamatan Limpung Kabupaten Batang (Other). Universitas Negeri Semarang. Diambil dari https://lib.unnes.ac.id/21074/

Peterson. (2002). Reculturing Schools. Diambil 14 Agustus 2011, dari http://smhp.psych.ucla.edu/qf/burnout_qt/reculturingschools.pdf

Presiden Republik Indonesia. (2005). Peraturan Pemerintah tentang Standar Nasional Pendidikan.

Safaria. (2004). Kepemimpinan. Edisi Pertama. Yogyakarta: Graha Ilmu.

Setiyati, S. (2014). Pengaruh Kepemimpinan Kepala Sekolah, Motivasi Kerja, dan Budaya Sekolah Terhadap Kinerja Guru. Jurnal Pendidikan Teknologi dan Kejuruan, 22(2), 200-206. https://doi.org/10.21831/jptk.v22i2.8931

Siregar, Y. (2018). Pengaruh Gaya Kepemimpinan Kepala Sekolah terhadap Kinerja Guru Bimbingan dan Konseling di SMA Negeri Jakarta Timur. Teraputik: Jurnal Bimbingan dan Konseling, 1 (3), 232-238-238. https://doi.org/10.26539/1388.

Siti Nurbaya \& Hr, A. (2016). Pengaruh Kompetensi, Disiplin Kerja, dan Lingkungan Sekolah terhadap Kinerja Guru Sekolah Dasar di Kecamatan Wajo Kota Makassar. Competitiveness : Jurnal Manajemen dan Bisnis, 10(2), 46-60.

Slameto. (2003). Belajar dan Faktor-faktor yang Mempengaruhinya. Jakarta: Rineka Cipta.

Sudarwan Danim. (2006). Visi Baru Manajemen Sekolah dari Unit Birokrasi ke Lembaga Akademik. Jakarta: Bumi Aksara.

Sumarno. (2009). Pengaruh Kepemimpinan Kepala Sekolah dan Profesionalisme Guru Terhadap Kinerja Guru Sekolah Dasar Negeri di Kecamatan Paguyangan Kabupaten Brebes. Semarang: Universitas Negeri Semarang.

Tobroni, (2008), Pendidikan Islam, Malang: UMM Press.

Wahjosumidjo. (2010). Kepemimpinan Kepala Sekolah: Tinjauan Teoritk dan Permasalahanya. Jakarta: Raja Grasindo Persada. 
Wibowo. (2011). Manajemen Kinerja. Jakarta: Raja Grafindo Persada.

Yukl, G.A. (2010). Leadership in Organization. ( $7^{\text {th }}$ ed.). Upper Saddle River: Prentice Hall.

Zamroni. (2000). Paradigma Pendidikan Masa Depan. Yogyakarta: Bayu Indra Grafika.

Zubaidah, S. (2015). Pengaruh Budaya Sekolah Dan Motivasi Kerja Guru Terhadap Mutu Pendidikan di SMK N 1 Pabelan. Prosiding Seminar Nasional Pendidikan. 